Einstein Award :

Dr. R. P. Feynman

THE third Einstein Award was made on March 14, the seventy-fifth birthday of Prof. Albert Einstein, to Dr. Richard Phillips Feynman, of the California Institute of Technology. This Award, which was established in 1950 by the Lewis and Rosa Strauss Memorial Fund, consists of a gold medal and fifteen thousand dollars, and the recipient is selected by a committee at the Institute for Advanced Study, Princeton, where Prof. Einstein works. The two previous Awards have been made to Dr. Julian S. Schwinger, of Harvard University, and Dr. Kurt Gödel, of the Institute for Advanced Study. Dr. Feynman, who is a graduate of the Massachusetts Institute of Technology, received his degree of Ph.D. from Princeton University in 1942 and was professor of physics in Cornell University during 1945-48. The main field of his research is quantum mechanics and, particularly, quantum electrodynamics. Both among the results and among the concepts in the latter field, some of the most important work developed during the past decade is due to him. In this respect, his treatment of quantum mechanics by the probability amplitude method, and the development of what is known as the Feynman diagram in accounting for possible particle transformations, are especially noteworthy.

\section{Textile Institute: Awards}

Honorary fellowship of the Textile Institute has been conferred on Prof. S. C. Harland, George Harrison professor of botany in the University of Manchester. Prof. Harland, who is the eleventh recipient of this honour, the highest that the Institute can bestow, is responsible for many notable advances in the volume, quality and stability of cotton crops throughout the world as a result of his work in plant breeding and genetics in the Sudan, the West Indies, Brazil and Peru, as well as in Great Britain. Other awards of the Institute have been made as follows : Institute Medal, to Mr. W. Howarth (general manager, Musgrave Spinning Co., Ltd.) and to Dr. C. S. Whewell (reader in textile finishing, University of Leeds) in recognition of distinguished service to the textile industry in general and to the Institute in particular ; Service Medal to Mr. J. C. H. Hurd (head of the Textile Department, Leicester College of Technology) for valuable services rendered to the Institute.

\section{Chemical Technology in Edinburgh : New Chair and Department}

Approval of the promotion of ordinances for the foundation of a chair of chemical technology and for the institution of a new degree of bachelor of technological science (B.Sc. Technological) has been given by the University of Edinburgh. This decision, taken after consultation with the Heriot-Watt College, Edinburgh, marks the* joint response of the University and the College to the urgent need for an increased supply of trained technologists. Both institutions are already making substantial contributions to the demand for training in applied science, and the proposed extension in what has come to be accepted as the fourth main branch of engineering industry is notably appropriate in view of local and national developments in the chemical industry. The new Department of Chemical Technology will be housed in the Heriot-Watt College, where ample provision for it has been made in the extension of the College premises now under con- struction. The new professor, although occupying the University chair, will act as head of the new Department in the College. The University has agreed to transfer to the College all the equipment in its Sub-Department of Technical Chemistry. The joint arrangement proposed provides a scheme whereby the requirements for the training of University and College students in this field may be met without duplication of effort. It is proposed to make a joint appeal to the appropriate firms in scotland and elsewhere for contributions towards the endowment of the chair and for suitable equipment to be used for teaching purposes.

\section{New Chairs at the University of Nottingham}

Is commemoration of the long and distinguished services of Lord and Lady Trent, the Boots Pure Drug Co., Ltd., has given to the University of Nottingham the sum of $£ 100,000$ for the endowment of two new professorial chairs to be known as the Lord Trent chair of pharmacentical chemistry and the Lady Trent chair of chemical engineering. The announcement of this generous benefaction was made at a special meeting of the Court at which the University accepted with deep regret the resignation, necessitated by continued ill-health, of Lord Trent from the office of chancellor. Lord Trent became a member of the University College Council in 1923 and was later chairman and president. By the charter of incorporation of the University granted in 1948 he was created chancellor. Until his recent retirement he had been since 1931 chairman of the Boots Pure Drug Co., which in 1949 contributed $£ 50,000$ to the University's endowment appeal. The natural interest of the Company in the development of chemistry found its expression so long ago as 1921 when, as Sir Jesse Boot, the first Lord Trent, to whose munificence the University owes its principal buildings at University Park, endowed the Sir Jesse Boot chair of chemistry. In founding a chair of pharmaceutical chemistry the Company has indicated its desire to eneourage the study of pharmacy and the development of research. The endowment of a chair of chemical engineering, following the recent institution of the Cripps chairs of metallurgy and of production engineering (Nature, December 19, p. 1129), will materially aid the University in its plans for the further development of the technological sciences.

\section{Year Book of the Royal Society}

THE recently issued Royal Society "Year Book" (pp. 311 ; from the Royal Society, Burlington House, London, W.1; 1954; 15s.), like its predecessors, is a volume which, apart from its usefulness as a work of reference, is a book to be dipped into for the host of scientific items-some important and some less so, but all interesting enough-which are to be found among its pages. The lists of Fellows and foreign mernbers occupy the first fifty pages and give their appointments, postal addresses, year of election to the Society, awards by the Society and service, if any, on the Council. It is interesting to note from these lists that there are four Fellows who were elected more than fifty years ago. The remaining five-sixths of the book is so full of miscellaneous information regarding the membership of the many types of committee and board, standing orders, procedure for the council, medal awards, lectures, financial trusts and funds, special fellowships and appointments, that even the listing of these items is a lengthy affair. One revealing 